\title{
Visceral adipose tissue mass in nonlactating dairy cows fed diets differing in energy density ${ }^{1}$
}

\author{
J. K. Drackley, ${ }^{* 2}$ R. L. Wallace,$\dagger^{3}$ D. Graugnard,${ }^{* 4}$ J. Vasquez, ${ }^{* 5}$ B. F. Richards, ${ }^{* 6}$ and J. J. Loor \\ *Department of Animal Sciences, and \\ †Department of Veterinary Clinical Medicine, University of Illinois, Urbana 61801
}

\begin{abstract}
Our objective was to determine dietary energy effects on feed intake, internal fat deposition, body condition score (BCS), visceral organ mass, and blood analytes in Holstein cows. Eighteen nonpregnant, nonlactating cows (BCS $=3.04 \pm 0.25$ ) were blocked based on initial BCS and were randomly assigned within each block to 2 treatments. Treatments were either high energy [HE; net energy for lactation $\left(\mathrm{NE}_{\mathrm{L}}\right)=1.62 \mathrm{Mcal} / \mathrm{kg}$ ] or low energy ( $\mathrm{LE} ; \mathrm{NE}_{\mathrm{L}}=1.35 \mathrm{Mcal} / \mathrm{kg}$ ) diets fed as total mixed rations for $8 \mathrm{wk}$. The LE diet consisted of $81.7 \%$ forage, including $40.5 \%$ wheat straw and $28.3 \%$ corn silage, whereas the HE diet contained $73.8 \%$ forage with no straw and $49.9 \%$ corn silage (dry matter basis). Cows were fed for ad libitum intake once daily at $0800 \mathrm{~h}$. Feed intake was recorded daily, blood was sampled at wk 1, 4, and 7, and BCS was assigned at wk 1, 4, and 7. Cows were killed following the 8-wk period, and visceral organs, mammary gland, and internal adipose tissues were weighed and sampled. The HE group had greater dry matter intake (15.9 vs. 11.2 $\pm 0.5 \mathrm{~kg} / \mathrm{d}$ ) and energy intakes than cows fed LE, but neutral detergent fiber intake did not differ ( 5.8 vs. 5.6 $\pm 0.25 \mathrm{~kg} / \mathrm{d}$ for $\mathrm{HE}$ and LE). Final body weight was greater for cows fed HE (807 vs. $750 \mathrm{~kg}$ ), but BCS did not differ between groups (3.52 vs. 3.47 for $\mathrm{HE}$ and LE). Omental (26.8 vs. $15.2 \pm 1.6 \mathrm{~kg} / \mathrm{d}$ ), mesenteric ( 21.5 vs. $11.2 \pm 1.9 \mathrm{~kg}$ ), and perirenal ( 8.9 vs. $5.4 \pm 0.9$ $\mathrm{kg}$ ) adipose tissue masses were larger in $\mathrm{HE}$ cows than in LE cows. Although subcutaneous adipose mass was not measured, carcass weight (including hide and subcutaneous fat) did not differ between $\mathrm{HE}(511 \mathrm{~kg})$ and LE (496 kg). Liver weight tended to be greater for cows
\end{abstract}

\footnotetext{
Received February 4, 2014.

Accepted February 16, 2014.

${ }^{1}$ Supported by USDA-CSREES and State of Illinois funds appropriated to the Illinois Agricultural Experiment Station.

${ }^{2}$ Corresponding author: drackley@illinois.edu

${ }^{3}$ Current address: 2328 County Rd AB, McFarland, WI 53558.

${ }^{4}$ Current address: 3031 Catnip Hill Pike, Nicholasville, KY 40356.

${ }^{5}$ Current address: 341 Pine Valley Ct., Linden, MI 48451.

${ }^{6}$ Current address: Dairy Science, Delaware Valley College, Doylestown, PA 18901.
}

fed HE, but weights of gastrointestinal tract, heart, and kidney did not differ. Serum insulin tended to be greater and the glucose to insulin ratio was lower for cows fed HE. Serum concentrations of $\beta$-hydroxybutyrate and cholesterol were greater for $\mathrm{HE}$ cows than for LE cows but concentrations of glucose, nonesterified fatty acids, total protein, and albumin did not differ. Final BCS was correlated with masses of omental $(\mathrm{r}=0.57)$, mesenteric $(\mathrm{r}=0.59)$, and perirenal $(\mathrm{r}=0.72)$ adipose tissue, but mesenteric adipose mass increased more as BCS increased for cows fed HE. The similar final BCS between HE and LE cows demonstrates that BCS may lack sensitivity to detect differences in visceral fat deposition that might increase risk for peripartal diseases and disorders.

Key words: adipose tissue, dry cow, energy intake

\section{INTRODUCTION}

Recent biomedical research has focused on the role of increased visceral (omental plus mesenteric) adipose tissue lipid accumulation in the pathogenesis of chronic disorders in humans such as metabolic syndrome (Gabriely et al., 2002; Yang et al., 2008; Catalano et al., 2010) and intestinal inflammatory disorders (Batra and Siegmund, 2012). In particular, enlarged mesenteric adipose tissue is implicated in development of insulin resistance and other abnormalities of the metabolic syndrome in humans (Yang et al., 2008) and rats (Catalano et al., 2010). Although dairy cattle accumulate relatively more fat in internal adipose depots and less in subcutaneous fat than do beef cattle (Wright and Russel, 1984), relatively little is known about changes in mass or function of internal fat depots in dairy cows, particularly during the periparturient period. Gibb et al. (1992) observed that fat represented $69 \%$ of the total body energy in newly calved Holstein-Friesian cows, and $20 \%$ of the total fat was associated with the digestive tract (omental and mesenteric adipose depots). Moreover, Gibb et al. (1992) determined that cows disproportionately mobilized a greater portion of that fat $(40 \%)$ compared with total body fat (34\%) during the first $8 \mathrm{wk}$ postpartum. 
Accumulation of lipids in the visceral adipose depots whose venous circulation drains to the liver (Ibrahim, 2010) could subject the liver to large amounts of NEFA and adipose-synthesized adipokines that may affect hepatic function, as observed in other species (Lafontan and Girard, 2008). The potential involvement of such factors in metabolic disorders of dairy cows has been discussed (Drackley et al., 2005; Sordillo et al., 2009). An "overnutrition syndrome" in periparturient dairy cows has been identified that shares many common features with the metabolic syndrome in humans and rodent models (Janovick et al., 2011). Our studies indicate that energy nutrition during the entire dry period, not just shortly prepartum, plays a determining role in periparturient hepatic and adipose metabolism and gene expression (Dann et al., 2006; Douglas et al., 2006; Loor et al., 2006; Ji et al., 2012). Consumption of excess energy relative to requirements during the dry period by allowing free access to moderate-energy diets leads to greater blood NEFA and BHBA, as well as hepatic fat accumulation postpartum (Dann et al., 2006; Douglas et al., 2006; Janovick et al., 2011). The extent to which visceral and other abdominal adipose tissues (e.g., perirenal) differentially accrete lipid in response to differences in diet (amount or source of energy) over short times such as a typical dry period length is not known.

Our hypothesis was that nonlactating cows fed a high-energy diet similar to those that have caused fatty liver in other studies (Douglas et al., 2006; Janovick et al., 2011) would accumulate more internal adipose tissue mass than cows fed a low-energy diet. Our objective was to determine dietary energy effects on feed and energy intake, BCS and BW, abdominal adipose tissue mass, carcass mass, visceral organs mass, and peripheral blood metabolites in nonlactating cows.

\section{MATERIALS AND METHODS}

\section{Experimental Design, Treatments, and Cow Management}

Eighteen nonpregnant, nonlactating Holstein cows $(\mathrm{BW}=656 \pm 29)$ were used in a completely randomized design study. Cows averaged 3.0 parities (range 2 to 4). Cows were stratified by initial BCS into 3 blocks $(<3.0,3.0$ to 3.75 , and $\geq 4.0)$. Within each block, cows were randomly assigned to treatments of either high energy $\left(\mathbf{H E} ; \mathrm{NE}_{\mathrm{L}}=1.62 \mathrm{Mcal} / \mathrm{kg}\right)$ or low energy $(\mathbf{L E}$; $\mathrm{NE}_{\mathrm{L}}=1.35 \mathrm{Mcal} / \mathrm{kg}$ ) diets fed as TMR for ad libitum intake for $8 \mathrm{wk}$ (Table 1). The HE diet contained $73.8 \%$ forage from alfalfa silage, alfalfa hay, and corn silage, whereas the LE diet contained $81.7 \%$ forage, including $40.5 \%$ wheat straw (DM basis). Cows were offered the
TMR once daily at $0800 \mathrm{~h}$ in amounts to allow 5 to $10 \%$ orts, and they had unlimited access to fresh water. The LE diet was formulated to be similar to high-bulk diets fed in previous experiments to limit energy intake when consumed at maximal DMI (Dann et al., 2006; Richards et al., 2009; Janovick and Drackley, 2010). Diets were mixed in a Keenan Klassik 140 mixer wagon (Richard Keenan \& Co. Ltd., Borris, County Carlow, Ireland) equipped with knives and serrated paddles; straw in large square bales was chopped directly by the mixer without preprocessing.

Cows were housed in indoor pens $(10 \times 15 \mathrm{~m})$ equipped with individual electronic transmission gates and transponders (American Calan Inc., Northwood, $\mathrm{NH}$ ) for access to feed. Each pen had 10 sand-bedded freestalls with at least one stall per cow. The experiment was conducted at the University of Illinois Dairy Cattle Research Unit (Urbana) from November 2007 through February 2008. Experimental procedures were approved by the Institutional Animal Care and Use Committee at the University of Illinois.

\section{Feed and Blood Sampling and Laboratory Analyses}

The amounts of TMR offered and orts removed were recorded daily and samples were collected every 2 wk. The TMR were sampled after feeding by remixing each cow's feed with a shovel and then obtaining grab samples, which were composited by diet. Feed and orts samples were oven-dried at $105^{\circ} \mathrm{C}$ for $24 \mathrm{~h}$ to measure DM content. Weekly TMR samples were pooled into 3 composites for nutrient analysis. All samples were analyzed at a commercial laboratory (Dairy One, Ithaca, NY) for contents of CP (method 984.13; AOAC International, 2000), NDF (Van Soest et al., 1991; using heat-stable $\alpha$-amylase and sodium sulfite), ADF (method 973.18; AOAC International, 2000), and fat (method 2003.05; AOAC International, 2000). The $\mathrm{NE}_{\mathrm{L}}$ content was estimated using summative equations as described by NRC (2001).

Blood was sampled from a tail artery or vein at wk 1, 4, and 7 into evacuated serum tubes (SST; Becton Dickinson Vacutainer Systems, Franklin Lakes, NJ) containing clot activator. Blood samples were centrifuged at 1,800 $\times g$ (Eppendorf Centrifuge 5804, Brinkmann Inst. Inc., Westbury, NY) to obtain serum. Serum samples were assayed for glucose, urea $\mathrm{N}$, creatinine, total protein, cholesterol, BHBA, and minerals using an auto-analyzer (Hitachi 917, Roche Diagnostic Corp., Indianapolis, IN), and diagnostic kits as described (Carlson et al., 2007), at the Small Animal Clinic Diagnostic Laboratory of the College of Veterinary Medicine (University of Illinois, Urbana). Serum samples were assayed for albumin, alkaline phosphatase, aspartate 
Table 1. Ingredient and analyzed nutrient composition of high energy (HE) and low energy (LE) diets (\% of DM unless otherwise noted)

\begin{tabular}{|c|c|c|}
\hline \multirow[b]{2}{*}{ Component } & \multicolumn{2}{|c|}{ Diet } \\
\hline & LE & $\mathrm{HE}$ \\
\hline \multicolumn{3}{|l|}{ Ingredient composition } \\
\hline Alfalfa silage & 9.70 & 17.92 \\
\hline Alfalfa hay & 3.24 & 6.00 \\
\hline Corn silage & 28.32 & 49.88 \\
\hline Wheat straw & 40.46 & - \\
\hline Ground shelled corn & 3.46 & 13.83 \\
\hline Whole cottonseed & - & 4.99 \\
\hline Soybean meal, $48 \%$ CP & 11.33 & 4.29 \\
\hline Urea & 0.24 & 0.19 \\
\hline Dicalcium phosphate & 0.32 & - \\
\hline Limestone & 0.65 & 0.62 \\
\hline Magnesium sulfate & 0.69 & 0.62 \\
\hline Magnesium chloride & 0.40 & 0.55 \\
\hline Magnesium oxide & 0.51 & 0.43 \\
\hline Mineral and vitamin premix ${ }^{1}$ & 0.19 & 0.18 \\
\hline Salt & 0.20 & 0.23 \\
\hline Vitamin $\mathrm{A}^{2}$ & 0.01 & 0.01 \\
\hline Vitamin $\mathrm{D}^{3}$ & 0.01 & 0.01 \\
\hline Vitamin $\mathrm{E}^{4}$ & 0.26 & 0.24 \\
\hline \multicolumn{3}{|l|}{ Nutrient composition } \\
\hline $\mathrm{DM}, \%$ & 51.9 & 50.0 \\
\hline $\mathrm{ME},{ }^{5} \mathrm{Mcal} / \mathrm{kg} \mathrm{DM}$ & 2.18 & 2.56 \\
\hline $\mathrm{NE}_{\mathrm{L}},{ }^{5} \mathrm{Mcal} / \mathrm{kg} \mathrm{DM}$ & 1.35 & 1.62 \\
\hline $\mathrm{CP}, \% \mathrm{DM}$ & 12.0 & 14.6 \\
\hline ADICP, \% DM & 0.7 & 0.7 \\
\hline $\mathrm{MP},{ }^{6} \mathrm{~g} / \mathrm{d}$ & 1,070 & 1,134 \\
\hline $\mathrm{NDF}, \% \mathrm{DM}$ & 51.7 & 35.1 \\
\hline Forage NDF, \% DM & 50.2 & 30.8 \\
\hline $\mathrm{ADF}, \% \mathrm{DM}$ & 36.4 & 23.5 \\
\hline $\mathrm{NFC},{ }^{5} \% \mathrm{DM}$ & 24.8 & 40.5 \\
\hline Fat, \% DM & 2.1 & 3.7 \\
\hline $\mathrm{Ca}, \% \mathrm{DM}$ & 0.64 & 0.67 \\
\hline $\mathrm{P}, \% \mathrm{DM}$ & 0.27 & 0.28 \\
\hline $\mathrm{Mg}, \% \mathrm{DM}$ & 0.63 & 0.62 \\
\hline $\mathrm{K}, \% \mathrm{DM}$ & 1.50 & 1.29 \\
\hline S, \% DM & 0.31 & 0.31 \\
\hline $\mathrm{Na}, \% \mathrm{DM}$ & 0.10 & 0.10 \\
\hline $\mathrm{Cl}, \% \mathrm{DM}$ & 0.68 & 0.64 \\
\hline $\mathrm{Fe}, \mathrm{mg} / \mathrm{kg}$ of $\mathrm{DM}$ & 306 & 339 \\
\hline $\mathrm{Zn}, \mathrm{mg} / \mathrm{kg}$ of $\mathrm{DM}$ & 80 & 78 \\
\hline $\mathrm{Cu}, \mathrm{mg} / \mathrm{kg}$ of $\mathrm{DM}$ & 14 & 15 \\
\hline $\mathrm{Mn}, \mathrm{mg} / \mathrm{kg}$ of DM & 72 & 70 \\
\hline
\end{tabular}

${ }^{1}$ Contained a minimum of $5 \% \mathrm{Mg}, 10 \% \mathrm{~S}, 7.5 \% \mathrm{~K}, 2.0 \% \mathrm{Fe}, 3.0 \% \mathrm{Zn}$ $3.0 \% \mathrm{Mn}, 5,000 \mathrm{mg} / \mathrm{kg}$ of $\mathrm{Cu}, 250 \mathrm{mg} / \mathrm{kg}$ of I, $40 \mathrm{mg} / \mathrm{kg}$ of Co, 150 $\mathrm{mg} / \mathrm{kg}$ of Se, $2,200 \mathrm{kIU} / \mathrm{kg}$ of vitamin $\mathrm{A}, 660 \mathrm{kIU} / \mathrm{kg}$ of vitamin $\mathrm{D}_{3}$, and $7,700 \mathrm{IU} / \mathrm{kg}$ of vitamin $\mathrm{E}$.

${ }^{2}$ Contained 30,000 kIU/kg.

${ }^{3}$ Contained 5,009 kIU $/ \mathrm{kg}$.

${ }^{4}$ Contained 44,000 IU $/ \mathrm{kg}$.

${ }^{5}$ Calculated using the NRC (2001) model and assumptions.

${ }^{6}$ Calculated using the NRC (2001) model at predicted DMI of 11.9 $\mathrm{kg} / \mathrm{d}$ and $12.8 \mathrm{~kg} / \mathrm{d}$ for $\mathrm{LE}$ and HE diets.

aminotransferase, $\gamma$-glutamyltransferase, and sorbitol dehydrogenase using autoanalyzer techniques (Carlson et al., 2007). Serum samples were analyzed for concentration of NEFA (NEFA C kit; Wako Chemicals USA Inc., Richmond, VA) with the modifications of Johnson and Peters (1993). Serum insulin was measured using a radioimmunoassay kit (Coat-a-Count Insulin kit; Diag- nostic Products Corp., Los Angeles, CA) according to the modified procedures of Studer et al. (1993).

Cow BW were determined at the start of the study and before harvest (i.e., final BW). A 5-point scoring scale $(1=$ emaciated to $5=$ obese $)$ was used to assign BCS by 2 trained individuals before assignment to treatments and at wk 1, 4, and 7 (Wildman et al., 1982).

\section{Tissue Weighing and Sampling}

At the end of the 8-wk treatment period, cows were euthanized by captive bolt at the College of Veterinary Medicine diagnostic facilities (University of Illinois) after an overnight period without feed. After exsanguination, the $\mathrm{BW}$ was determined and is referred to as post-blood shrunk BW (SBW). Immediately after death, all visceral tissues, including heart, liver, total gastrointestinal tract, and kidneys as well as mammary gland, were separated and weighed. The internal adipose tissue masses in omental, mesenteric, and perirenal depots were dissected and weighed. The sum of the omental and mesenteric adipose tissues was analyzed as total visceral adipose tissue. The sum of omental, mesenteric, and perirenal tissues was termed total abdominal adipose tissue. The final weight of the animal after removal of blood, all internal organs, and mammary gland was termed the carcass weight.

\section{Statistical Analysis}

All data were examined for normality of distribution and homogeneity of residuals variance using Proc Univariate of SAS (release 9.2; SAS Institute Inc., Cary, NC). Data for serum NEFA were subjected to the BoxCox algorithm and were transformed accordingly to remove heterogeneity of variance among residuals; the $P$-values presented are for transformed data.

Data were analyzed using Proc Mixed of SAS. Nonrepeated data (BW, BCS, and tissue and organ masses) were analyzed as a randomized design with a mixed model containing the fixed effect of diet; models also contained the covariates of initial BCS and pretrial BW as continuous variables if $P<0.15$. The final models for BCS and all adipose depots contained the linear covariate of initial BCS, whereas final models for BW, SBW, and carcass weight contained both initial BCS and pretrial BW as linear covariates. The repeated data for DMI, energy intakes, and blood variables were analyzed as a randomized design with a mixed model containing fixed effects of diet, week, and the diet $\times$ week interactions as well as the initial BCS as a continuous covariate. The experimental unit was cow within diet, and the covariance structure was first-order autoregres- 
Table 2. Intakes, BW, BCS, visceral organs mass, mammary gland mass, and internal adipose tissue mass in nonlactating cows fed high energy (HE) or low energy (LE) diets

\begin{tabular}{|c|c|c|c|c|}
\hline \multirow[b]{2}{*}{ Variable } & \multicolumn{2}{|c|}{ Diet } & \multirow[b]{2}{*}{ SEM } & \multirow{2}{*}{$\frac{P \text {-value }}{\text { Diet }}$} \\
\hline & LE & $\mathrm{HE}$ & & \\
\hline $\mathrm{DMI},{ }^{1} \mathrm{~kg} / \mathrm{d}$ & 11.2 & 15.9 & 0.53 & $<0.001$ \\
\hline NDF intake, ${ }^{1} \mathrm{~kg} / \mathrm{d}$ & 5.8 & 5.6 & 0.25 & 0.58 \\
\hline ME intake,${ }^{1} \mathrm{Mcal} / \mathrm{d}$ & 24.7 & 40.8 & 1.17 & $<0.001$ \\
\hline $\mathrm{NE}_{\mathrm{L}}$ intake, ${ }^{1} \mathrm{Mcal} / \mathrm{d}$ & 15.3 & 25.8 & 0.73 & $<0.0001$ \\
\hline Final live BW, kg & 751 & 806 & 17.3 & 0.04 \\
\hline Post-blood SBW, ${ }^{2} \mathrm{~kg}$ & 698 & 734 & 16.2 & 0.14 \\
\hline Initial BCS & 3.00 & 3.08 & 0.24 & 0.81 \\
\hline Final BCS & 3.47 & 3.52 & 0.090 & 0.69 \\
\hline Carcass, ${ }^{3} \mathrm{~kg}$ & 496 & 511 & 13.4 & 0.45 \\
\hline Omental adipose, $\mathrm{kg}$ & 15.2 & 26.8 & 1.57 & $<0.001$ \\
\hline Mesenteric adipose, $\mathrm{kg}$ & 11.2 & 21.5 & 1.90 & 0.002 \\
\hline Total visceral adipose ${ }^{4} \mathrm{~kg}$ & 26.5 & 48.3 & 2.70 & $<0.001$ \\
\hline Perirenal adipose, $\mathrm{kg}$ & 5.38 & 8.87 & 0.87 & 0.01 \\
\hline Total abdominal adipose, ${ }^{5} \mathrm{~kg}$ & 31.8 & 57.2 & 3.08 & $<0.001$ \\
\hline Mammary gland, kg & 17.7 & 18.4 & 1.61 & 0.78 \\
\hline Gastrointestinal tract, $\mathrm{kg}$ & 43.3 & 47.7 & 2.61 & 0.27 \\
\hline Kidneys, kg & 1.74 & 2.01 & 0.15 & 0.26 \\
\hline Liver, kg & 9.0 & 10.5 & 0.54 & 0.07 \\
\hline Heart, kg & 4.01 & 4.02 & 0.094 & 0.90 \\
\hline
\end{tabular}

sive. The Kenward-Roger method was used to calculate denominator degrees of freedom. Least squares means were estimated using the REML method. Where the number of observations per mean differed, the larger standard error is presented.

Relationships among visceral adipose masses and BCS were determined by regression analysis using Proc GLM in SAS (SAS Institute Inc.). The regression model used a dummy variable technique with explicit intercepts to simultaneously fit 2 lines and force direct estimation of the intercepts (Anonymous, 2005). Slopes and intercepts were compared directly using 2 contrasts, and a third contrast tested for coincident lines (Anonymous, 2005). Pearson correlation coefficients among variables were generated using Proc Corr of SAS. Significance was declared for $P$-values $<0.05$ and trends are discussed if $P<0.10$.

\section{RESULTS}

Analyzed composition of the diets is shown in Table 1. Cows consumed the diets for a mean of $57.6 \mathrm{~d}$ (SD $=3.8$ ) for each diet. Cows fed HE consumed $42 \%$ more DM than cows fed LE (Table 2). Intake of NDF was similar between groups ( 5.8 vs. $5.6 \mathrm{~kg} / \mathrm{d}$ for LE and $\mathrm{HE})$. As a result of different DMI and differing dietary energy density, calculated intakes of $\mathrm{ME}$ and $\mathrm{NE}_{\mathrm{L}}$ were, respectively, 65 and $69 \%$ greater for cows fed HE than for those fed LE. Final BW was greater $(P<0.05)$ for cows fed HE than for those fed LE. However, final BCS $(P=0.69)$ and carcass weight $(P=0.43)$ did not differ significantly between dietary groups. Carcass weight as a percentage of final BW did not differ $(P=0.21)$ between cows fed LE (65.9\%) and HE (63.6\%).

Masses of omental adipose $(P<0.001)$, mesenteric adipose $(P=0.02)$, and perirenal adipose $(P=0.01)$ were $76.3,92.0$, and $64.9 \%$ greater for cows fed HE compared with those fed LE (Table 2). When expressed as percentages of final BW or carcass weight, all adipose tissues were greater for HE than for LE (data not presented). Weights of mammary gland, total gastrointestinal tract, kidneys, and heart did not differ significantly between groups when expressed either as mass (Table 2) or as percentages of final BW (not presented). Liver mass tended $(P=0.07)$ to be greater for cows fed HE. Liver mass as a percentage of final BW did not differ $(P=0.33)$ between diets (1.21 vs. $1.33 \%$ for LE and HE), but when expressed as a percentage of carcass weight, liver mass tended $(P=0.10)$ to be greater for HE than for LE (1.82 vs. $2.09 \%$ for LE and $\mathrm{HE}$ ).

The concentration of glucose in serum did not differ between diets, but serum insulin tended $(P=0.09)$ to be greater for cows fed HE than for those fed LE (Table 3). As a result, the glucose to insulin ratio was greater $(P=0.02)$ for cows fed LE than for those fed 
HE. Concentrations of NEFA, urea N, total protein, albumin, and globulin did not differ significantly between diets (Table 3). Concentrations of urea $\mathrm{N}$ and albumin increased over time, but interactions of diet and week were not significant. The concentration of BHBA was greater $(P=0.005)$ for cows fed HE. Total cholesterol in serum was greater $(P=0.02)$ for cows fed HE, and the diet $\times$ week interaction was significant. Cholesterol increased with time for cows fed $\mathrm{HE}(114,117$, and 135 $\mathrm{mg} / \mathrm{dL}$ at wk 1, 4, and 7) but decreased for cows fed LE $(118,95$, and $87 \mathrm{mg} / \mathrm{dL})$. Creatinine tended $(P=0.06)$ to be lower for HE than for LE, and increased with time for both diets. Serum concentrations of $\mathrm{Ca}, \mathrm{P}, \mathrm{Na}$, $\mathrm{K}, \mathrm{Cl}$, and $\mathrm{Mg}$ did not differ $(P \geq 0.30)$ between diets, but all increased with time.

Activity of alkaline phosphatase in serum tended $(P$ $=0.10)$ to be greater for cows fed LE (Table 3). Alkaline phosphatase activity increased with time, but with a tendency for a diet $\times$ time interaction $(P=0.08)$ such that a greater increase occurred in cows fed LE (45.8, 50.3 , and $61.8 \mathrm{U} / \mathrm{L}$ at wk 1,4 , and 7) than in cows fed $\mathrm{HE}(40.4,43.9$, and $45.2 \mathrm{U} / \mathrm{L})$. Activities of aspartate aminotransferase, $\gamma$-glutamyltransferase, and sorbitol dehydrogenase were not affected by diet; sorbitol dehydrogenase increased $(P<0.001)$ with time. The diet $\times$ week interaction $(P=0.02)$ for $\gamma$-glutamyltransferase indicated that activities decreased over time for cows fed LE (22.1, 22.2, and 19.8 U/L for wk 1, 4, and 7) but increased for cows fed $\mathrm{HE}(18.2,21.6$, and $21.7 \mathrm{U} / \mathrm{L})$.

Regression analysis revealed that mass of mesenteric adipose tissue was greater and increased more as final
BCS increased for cows fed HE compared with cows fed LE (Figure 1). Slopes for increase in omental adipose tissue with increasing final BCS did not differ between diets (data not presented). Both slopes $(P=0.02)$ and intercepts $(P=0.04)$ from regression of mesenteric adipose tissue as a percentage of post-blood SBW on omental adipose tissue as a percentage of post-blood SBW differed between diets (Figure 2).

Correlations among selected variables relating to body lipid storage are presented in Table 4 . Final BW was more highly correlated $(\mathrm{r}=0.67)$ with initial BCS than with final BCS $(\mathrm{r}=0.38 ; P=0.12)$. Final BW was strongly related to carcass weight $(\mathrm{r}=0.90)$, as well as masses of omental $(\mathrm{r}=0.63)$ and perirenal $(\mathrm{r}=$ $0.60)$ adipose tissues; however, final BW only tended ( $P$ $=0.06)$ to be correlated with mesenteric adipose mass $(\mathrm{r}=0.46)$. Final BCS was more highly correlated with masses of omental $(\mathrm{r}=0.57)$, mesenteric $(\mathrm{r}=0.59)$, and perirenal $(\mathrm{r}=0.72)$ adipose tissue than with carcass weight $(\mathrm{r}=0.38 ; P=0.12)$. Masses of the 3 abdominal fat depots were strongly correlated with each other, but carcass mass was only modestly correlated $(\mathrm{r}=0.39 ; P$ $=0.11)$ with mass of mesenteric adipose tissue.

\section{DISCUSSION}

\section{Experimental Model}

Cows were provided ad libitum access to diets representing typical "controlled energy" diets (LE) or higherenergy close-up diets (HE) fed to dry cows. Previous

Table 3. Metabolites, minerals, enzymes, and insulin in plasma and serum insulin in nonlactating cows fed high energy (HE) or low energy (LE) diets

\begin{tabular}{|c|c|c|c|c|c|c|}
\hline \multirow[b]{2}{*}{ Analyte } & \multicolumn{2}{|c|}{ Diet } & \multirow[b]{2}{*}{ SEM } & \multicolumn{3}{|c|}{$P$-value } \\
\hline & LE & $\mathrm{HE}$ & & Diet & Week & Diet $\times$ week \\
\hline Glucose, $\mathrm{mg} / \mathrm{dL}$ & 68.5 & 67.6 & 1.05 & 0.53 & 0.48 & 0.65 \\
\hline Insulin, $\mu \mathrm{IU} / \mathrm{mL}$ & 21.9 & 28.8 & 2.78 & 0.09 & 0.70 & 0.50 \\
\hline Glucose:insulin & 3.81 & 2.66 & 0.31 & 0.02 & 0.28 & 0.38 \\
\hline NEFA, mmol/L & 0.10 & 0.12 & 0.012 & 0.20 & 0.30 & 0.18 \\
\hline $\mathrm{BHBA}, \mathrm{mmol} / \mathrm{L}$ & 0.36 & 0.48 & 0.025 & 0.005 & 0.83 & 0.82 \\
\hline Cholesterol, $\mathrm{mg} / \mathrm{dL}$ & 100 & 122 & 5.9 & 0.02 & 0.16 & $<0.001$ \\
\hline Urea $\mathrm{N}, \mathrm{mg} / \mathrm{dL}$ & 12.7 & 13.3 & 0.53 & 0.42 & 0.02 & 0.91 \\
\hline Total protein, g/dL & 7.87 & 7.80 & 0.24 & 0.85 & 0.81 & 0.63 \\
\hline Albumin, $\mathrm{g} / \mathrm{dL}$ & 3.52 & 3.56 & 0.078 & 0.73 & $<0.001$ & 0.96 \\
\hline Globulin, $\mathrm{g} / \mathrm{dL}$ & 4.35 & 4.24 & 0.26 & 0.78 & 0.27 & 0.56 \\
\hline Creatinine, $\mathrm{mg} / \mathrm{dL}$ & 1.01 & 0.87 & 0.048 & 0.06 & 0.02 & 0.16 \\
\hline Calcium, mg/dL & 9.08 & 9.15 & 0.16 & 0.76 & $<0.001$ & 0.68 \\
\hline Phosphorous, mg/dL & 6.05 & 5.86 & 0.17 & 0.43 & 0.07 & 0.72 \\
\hline Sodium, mmol/L & 137.5 & 136.8 & 1.99 & 0.80 & 0.009 & 0.79 \\
\hline Potassium, mmol/L & 4.42 & 4.28 & 0.090 & 0.30 & 0.006 & 0.18 \\
\hline Chloride, $\mathrm{mmol} / \mathrm{L}$ & 97.8 & 96.3 & 1.81 & 0.55 & 0.007 & 0.81 \\
\hline Magnesium, mg/dL & 2.52 & 2.55 & 0.049 & 0.66 & 0.01 & 0.75 \\
\hline Alkaline phosphatase, U/L & 52.7 & 43.2 & 3.90 & 0.10 & 0.003 & 0.08 \\
\hline Aspartate aminotransferase, U/L & 65.1 & 62.9 & 5.23 & 0.77 & 0.07 & 0.82 \\
\hline$\gamma$-Glutamyltransferase, U/L & 21.4 & 20.5 & 2.10 & 0.78 & 0.04 & 0.02 \\
\hline Sorbitol dehydrogenase, U/L & 9.0 & 9.9 & 1.26 & 0.63 & $<0.001$ & 0.31 \\
\hline
\end{tabular}




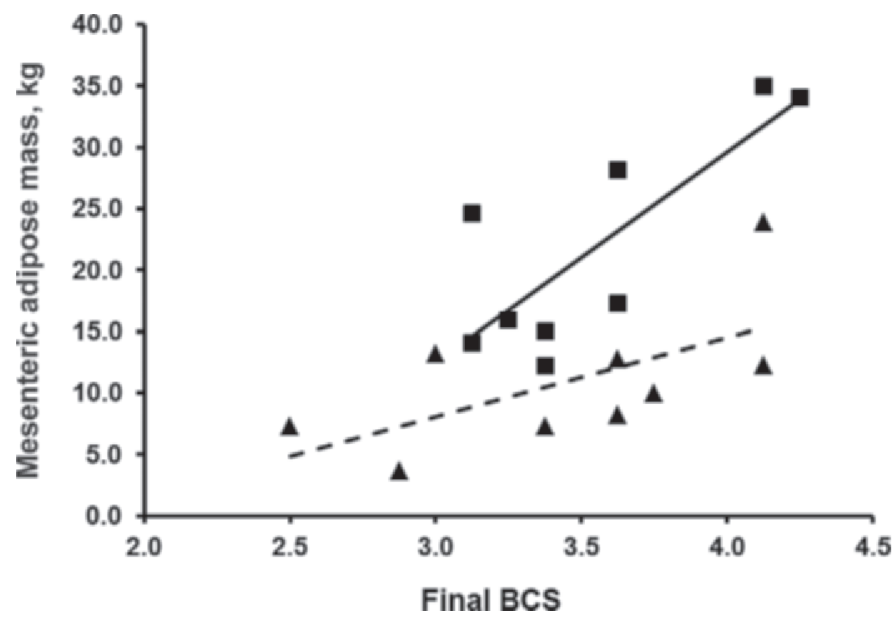

Figure 1. Regression analysis of mesenteric adipose tissue mass (y) versus final BCS $(\mathrm{x})$ for nonpregnant, nonlactating cows fed high energy (HE; $\boldsymbol{\square}$ and solid line) or low energy (LE; $\boldsymbol{\Delta}$ and broken line) diets. For cows fed $\mathrm{HE}$, the regression equation was $\mathrm{y}=17.2 \pm 4.6 \mathrm{x}-39.1$ $\pm 16.3\left(\mathrm{R}^{2}=0.63\right)$. For cows fed $\mathrm{LE}$, the regression equation was $\mathrm{y}=$ $6.4 \pm 3.3 \mathrm{x}-11.2 \pm 16.3\left(\mathrm{R}^{2}=0.39\right)$. The final combined model $\left(\mathrm{R}^{2}=\right.$ $0.72)$ showed that the regression lines were different $(P<0.01)$; slopes tended $(P=0.08)$ to differ but the intercepts did not $(P=0.19)$.

studies by our group (Dann et al., 2006; Richards et al., 2009; Janovick and Drackley, 2010; Janovick et al., 2011; Graugnard et al., 2012; Ji et al., 2012) and others (Vickers et al., 2013) have shown that controlling energy intake during the dry period to near requirements for maintenance and pregnancy results in improved postpartum energy balance, lower NEFA and BHBA in blood, and less fat accumulation in liver postpartum. The role of internal adipose tissues in mediating or contributing to these responses is unknown (Drackley

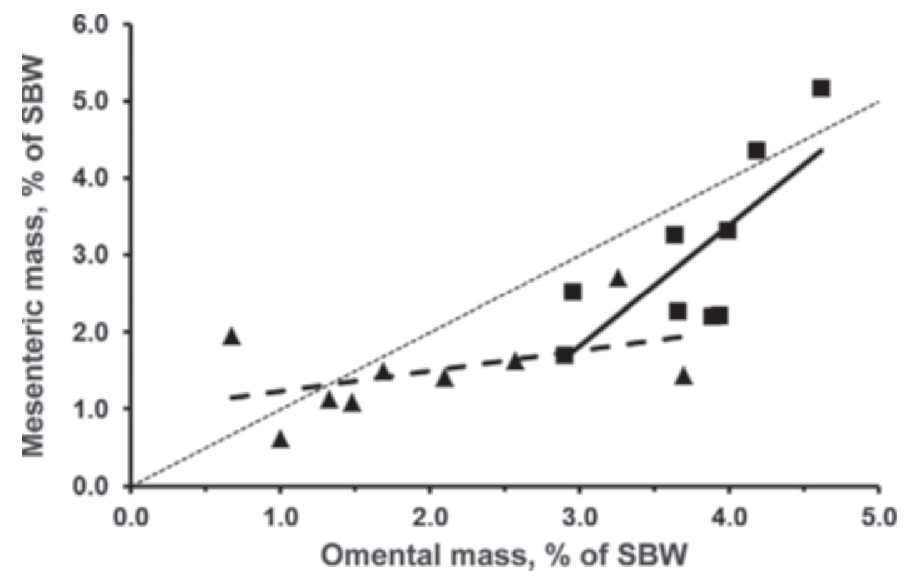

Figure 2. Regression analysis of mesenteric adipose tissue mass as a percentage of final post-blood shrunk BW (SBW; y) versus omental adipose tissue mass as a percentage of final post-blood SBW (x) for nonpregnant, nonlactating cows fed high energy (HE; $\mathbf{a n d}$ solid line) or low energy (LE; $\boldsymbol{\Delta}$ and broken line) diets. For cows fed HE, the regression equation was $\mathrm{y}=1.57 \pm 0.44 \mathrm{x}-2.90 \pm 1.67\left(\mathrm{R}^{2}=0.58\right)$. For cows fed LE, the regression equation was $\mathrm{y}=0.27 \pm 0.24 \mathrm{x}-0.96$ $\pm 0.52\left(\mathrm{R}^{2}=0.21\right)$. The final combined model $\left(\mathrm{R}^{2}=0.72\right)$ showed that the regression lines were different $(P<0.05)$; both slopes $(P=0.02)$ and intercepts $(P=0.04)$ differed between diets. The light dotted line is the line of equivalence.

et al., 2005). Our hypothesis was that excessive energy intake during the dry period leads to greater accumulation of lipid in visceral adipose tissues whose venous drainage is via the portal vein. Consequently, as lipolysis increases around and after parturition, the liver would be directly "flooded" with NEFA from visceral adipose mobilization (Reynolds, 2002). Furthermore, the liver would be directly exposed to various adipokines synthesized and secreted from visceral adipose

Table 4. Pearson correlation coefficients among BW, BCS, carcass mass, and masses of omental, mesenteric, and perirenal adipose depots ${ }^{1}$

\begin{tabular}{|c|c|c|c|c|c|c|c|c|c|}
\hline & $\begin{array}{l}\text { Post-blood } \\
\text { SBW }^{2}\end{array}$ & $\begin{array}{c}\text { Initial } \\
\text { BCS }\end{array}$ & $\begin{array}{l}\text { Final } \\
\text { BCS }\end{array}$ & Carcass & Omental & Mesenteric & Perirenal & $\begin{array}{c}\text { Total } \\
\text { visceral }\end{array}$ & $\begin{array}{c}\text { Total } \\
\text { abdominal }\end{array}$ \\
\hline Final BW & $\begin{array}{c}0.93 \\
(<0.001)\end{array}$ & $\begin{array}{l}0.67 \\
(0.002)\end{array}$ & $\begin{array}{c}0.38 \\
(0.12)\end{array}$ & $\begin{array}{c}0.90 \\
(<0.001)\end{array}$ & $\begin{array}{l}0.63 \\
(0.005)\end{array}$ & $\begin{array}{l}0.46 \\
(0.057)\end{array}$ & $\begin{array}{l}0.60 \\
(0.009)\end{array}$ & $\begin{array}{l}0.58 \\
(0.011)\end{array}$ & $\begin{array}{l}0.60 \\
(0.008)\end{array}$ \\
\hline Initial BCS & & 1.00 & $\begin{array}{c}0.85 \\
(<0.001)\end{array}$ & $\begin{array}{l}0.69 \\
(0.001)\end{array}$ & $\begin{array}{l}0.67 \\
(0.002)\end{array}$ & $\begin{array}{l}0.57 \\
(0.014)\end{array}$ & $\begin{array}{c}0.75 \\
(<0.001)\end{array}$ & $\begin{array}{l}0.66 \\
(0.003)\end{array}$ & $\begin{array}{l}0.70 \\
(0.001)\end{array}$ \\
\hline Omental & & & & & 1.00 & $\begin{array}{c}0.78 \\
(<0.001)\end{array}$ & $\begin{array}{c}0.73 \\
(<0.001)\end{array}$ & $\begin{array}{c}0.95 \\
(<0.001)\end{array}$ & $\begin{array}{c}0.94 \\
(<0.001)\end{array}$ \\
\hline Mesenteric & & & & & & 1.00 & $\begin{array}{c}0.80 \\
(<0.001)\end{array}$ & $\begin{array}{c}0.94 \\
(<0.001)\end{array}$ & $\begin{array}{c}0.94 \\
(<0.001)\end{array}$ \\
\hline Perirenal & & & & & & & 1.00 & $\begin{array}{c}0.81 \\
(<0.001)\end{array}$ & $\begin{array}{c}0.87 \\
(<0.001)\end{array}$ \\
\hline
\end{tabular}

${ }^{1}$ Correlations, with probability of correlation different than zero in parentheses.

${ }^{2}$ Shrunk BW after death and removal of blood. 
tissues as demonstrated in rats (Gabriely et al., 2002). These changes might contribute to peripartal disease and poor transitions to lactation in dairy cows (Drackley et al., 2005; Sordillo et al., 2009).

We used nonlactating and nonpregnant cows to compare effects of dietary energy amount and source on body lipid storage over the length of a typical dry period. We acknowledge that responses of nonpregnant cows to dietary energy supply may differ from those of pregnant cows because of differences in nutrient requirements and endocrine environment. However, our main focus was on dietary-induced partitioning of fat stores among abdominal depots versus carcassassociated depots. Data demonstrating that partitioning of fat among depots may be affected by pregnancy per se are scarce and are confounded by differences in energy intake or total body fatness at slaughter. Smith and Baldwin (1974) reported that pregnant and nonpregnant nonlactating Jersey cows had similar amounts and proportions of visceral fat, but both were greater than for lactating cows. Butler-Hogg et al. (1985) found that late-pregnant dry cows and nonpregnant dry cows had similar proportions of omental, mesenteric, and perirenal fat, but total fat storage in the nonpregnant cows was approximately twice that of pregnant cows. The proportion of total fat found in the carcass was similar between the 2 groups of cows, although within carcass the proportion of subcutaneous fat was greater in nonpregnant cows and the proportion of intermuscular fat was greater for pregnant cows (Butler-Hogg et al., 1985). In growing beef heifers consuming the same amount of ME relative to metabolic body size, empty body energy gain was not consistently different between pregnant and nonpregnant animals (Ferrell et al., 1976). Furthermore, pregnancy had little effect on visceral organ mass in beef heifers (Scheaffer et al., 2001).

Our model allowed comparison of dietary effects on masses of internal adipose tissues, visceral organs, and carcass of nonlactating cows. Effects of dietary energy amount and source are confounded in this design, but this situation represents the norm on commercial farms. Because cows were not pregnant, both groups consumed an excess of dietary energy and gained BCS over the 8-wk feeding period.

\section{DMI, Energy Intakes, BCS, and Visceral Adipose Mass}

Cows fed the HE diet had greater DMI and greater intakes of $\mathrm{ME}$ and $\mathrm{NE}_{\mathrm{L}}$ than cows fed the LE diet, confirming that unlimited access to high-energy diets leads to overconsumption of energy in nonlactating cows (Dann et al., 2006; Douglas et al., 2006; Janovick and Drackley, 2010). Although cows fed HE were expected to have greater DMI than cows fed LE, actual DMI for the nonpregnant cows fed HE $(15.9 \mathrm{~kg} / \mathrm{d})$ in our study were considerably greater than predicted $(12.6 \mathrm{~kg} / \mathrm{d})$ for pregnant dry cows by NRC (2001). Our results for differences of energy intake in nonlactating cows are consistent with previous reports in which increased energy balance during the dry period decreased postpartum energy balance and increased blood NEFA and BHBA (Dann et al., 2006; Douglas et al., 2006, Janovick et al., 2011). Our results also substantiated previous findings that decreasing dietary energy density by including chopped straw in the TMR effectively limited energy intake in dry cows (Dann et al., 2006; Janovick and Drackley, 2010; Graugnard et al., 2012). It has long been known that rumen fill is a primary limiting factor for DMI in ruminants fed predominantly forage diets (Blaxter et al., 1961) and that forage NDF content is inversely related to voluntary intake of highforage diets (Jung and Allen, 1995). Cows in our study may have eaten to similar ruminal fill as constrained by NDF intake, because NDF intakes were similar between dietary groups.

Final BW were greater for cows fed HE as expected, consistent with greater energy intake over the 8-wk period. Surprisingly, however, final BCS did not differ between groups, despite the markedly greater masses of omental, mesenteric, and perirenal adipose depots in HE cows. As stated by Wright and Russel (1984), BCS assesses only the amount of subcutaneous fat at a given stage of production. Cattle of dairy breeds accumulate relatively more fat in internal adipose depots and less in subcutaneous fat than beef breeds (Wright and Russel, 1984). Nevertheless, Wright and Russel (1984) and Waltner et al. (1994) found that BCS was strongly predictive of overall body lipid storage in nonlactating Friesian and lactating Holstein cows, respectively. A limitation of our study is that we did not measure subcutaneous fat thickness or mass. In our study, however, the numerical difference in carcass weight between diets did not approach significance, which suggests that the internal adipose depots were relatively more responsible for overall increases in energy storage for cows fed HE. Whether all body adipose depots increase and decrease lipid storage in concert over the lactation cycle remains controversial. Data from Butler-Hogg et al. (1985) were interpreted to indicate that all adipose depots generally mobilized and repleted similar proportions of body lipid, although in vitro data from the same cows demonstrated that lipolytic rates were greater in subcutaneous than in omental adipocytes (Smith and Walsh, 1988). In contrast, Gibb et al. (1992) found that proportional mobilization of omental, mesenteric, and perirenal fat was greater than the proportional 
mobilization of total body fat during the first 8 wk of lactation. Although useful for long-term management of overall energy storage, our data indicate that assessing BCS changes during the relatively short duration of a dry period may not be sensitive enough to detect differences in internal fat storage that are potentially important physiologically.

\section{Visceral Organ Mass}

Visceral organ mass in ruminants increases with increased DMI or nutrient supply and does not change with physiological state per se (Scheaffer et al., 2001; Reynolds et al., 2004; McLeod et al., 2007). In agreement with the greater DMI and nutrient intakes, liver weight was greater in cows fed HE, but small differences between dietary means for total gastrointestinal tract and kidneys did not achieve statistical significance. Supplementing a grass silage-based prepartal diet with barley grain tended to increase mesenteric fat weight and decrease total stomach weight relative to cows consuming only the grass silage diet (Reynolds et al., 2004). A similar difference in partitioning of ME between HE and LE in our study could have resulted in increased visceral fat storage without large increases in gastrointestinal tract mass expected from greater DMI and energy intakes. Except for liver expressed as a percentage of carcass weight, masses of the visceral organs measured did not differ proportionally to whole-body or carcass mass.

\section{Peripheral Blood Analytes}

Although we did not measure baseline concentrations of metabolites in blood before the start of nutritional treatments, we were primarily interested in differential responses of these variables to dietary treatments over the 8-wk feeding period. Greater intakes of ME and MP resulted in increased serum insulin in cows fed HE, as expected. Coupled with unchanged glucose concentration, this resulted in a decreased glucose:insulin ratio for cows fed HE, similar to previous results (Dann et al., 2006; Janovick et al., 2011). Such changes indicate the possibility of altered insulin response, although Ji et al. (2012) found that responsiveness of bovine adipose tissue to insulin signaling in vitro was not altered by energy excess during the last $3 \mathrm{wk}$ prepartum. Plasma NEFA were low in both groups in our study, reflecting the positive energy balance. In cows during positive energy balance, circulating BHBA originates mainly from alimentary modification of butyrate (Reynolds, 2002). The greater plasma BHBA in cows fed HE was likely due to greater DMI and, thus, more rumen-fermentable OM compared with the LE group.
Cholesterol is synthesized from acetate in the liver and small intestinal epithelium of ruminants (Nestel et al., 1978). The greater plasma concentration of cholesterol in HE cows could be due to the greater DMI and thereby greater duodenal flow of long-chain fatty acids, which would increase demand for cholesterol in lipoprotein synthesis. Increased supply of rumen acetate from greater intake of the HE diet also may have contributed to cholesterol synthesis.

Dietary energy intake did not affect concentrations of urea N, total protein, albumin, or globulin. These results indicate that dietary MP supply was likely sufficient but not excessive for cows in either dietary group. Creatinine concentration was slightly higher for LE cows. Creatinine is usually used as an indicator of kidney function (Ulleberg et al., 2011), but plasma or serum creatinine in cows also can be affected by alterations in acid-base balance (Hu et al., 2007) or mobilization of muscle mass during the peripartal period (Simmons et al., 1994). The cause of the small elevation of creatinine in LE cows is difficult to determine.

Serum minerals and electrolytes as well as selected enzymes were measured to determine any adverse effects of diet on liver or kidney function. All were within normal ranges for cattle. Serum minerals and electrolytes did not differ between diets but increased during the 8 -wk study. The increases with time may reflect longer-term adaptations to the changing physiological state from lactation to nonlactating.

Activities of aspartate aminotransferase and sorbitol dehydrogenase were measured to provide information on integrity of hepatocytes, whereas alkaline phosphatase and $\gamma$-glutamyl transferase were used to assess the hepatobiliary system (Tennant and Center, 2008). Overall, these tests revealed no evidence of liver damage, although minor differences were observed between dietary groups over time. Alkaline phosphatase in blood originates from bone as well as liver, and so the larger increases in alkaline phosphatase activity over time for cows fed LE may reflect a greater degree of bone remodeling due to osteoclast activity (Tennant and Center, 2008). Increased $\gamma$-glutamyl transferase in serum is interpreted as an indicator of chronic liver damage (Tennant and Center, 2008). Whether the small decrease over time for cows fed LE and small increase for cows fed $\mathrm{HE}$ indicates a potentially negative effect of $\mathrm{HE}$ on liver function is questionable.

\section{Mesenteric and Omental Adipose Tissues}

Visceral adipose tissues (omental and mesenteric) differ anatomically and physiologically from subcutaneous adipose tissue (Lafontan and Girard, 2008; Ibrahim, 2010). Studies in humans (Yang et al., 2008) 
and rats (Gabriely et al., 2002; Catalano et al., 2010) have implicated visceral adipose tissue accumulation as a cause of, or risk factor for, outcomes associated with the metabolic syndrome, such as insulin resistance and diabetes. Recent studies also suggest a role for visceral adipose tissues in intestinal inflammatory disorders (Batra and Siegmund, 2012). Of the visceral adipose tissues, increased mass of mesenteric adipose rather than omental adipose is believed to be the greater risk factor for disease in humans (Yang et al., 2008). The mRNA expression of adipokines is different between visceral and subcutaneous adipose tissues in humans (Dusserre et al., 2000) and rats (Gabriely et al., 2002), and global gene expression and lipid composition differ among the subcutaneous, epididymal, and mesenteric adipose tissues of mice (Caesar et al., 2010). Preliminary data from our laboratories demonstrated differences in gene expression among mesenteric, omental, perirenal, and subcutaneous adipose tissue of lactating cows (Loor et al., 2004). Differences in gene expression may contribute to differences in physiological function among depots, such as the greater catecholamine-stimulated lipolysis in visceral adipocytes compared with external adipocytes of humans and rodents (Van Harmelen et al., 1997; Lafontan and Girard, 2008). In dairy cows during the first $3 \mathrm{wk}$ postpartum, in vitro epinephrinestimulated lipolysis among adipose depots varied in the order omental $>$ subcutaneous $>$ mesenteric $>$ perirenal (Pike and Roberts, 1984). Similar results were reported in nonlactating and lactating ewes, in which basal and stimulated rates of lipolysis were greater in omental than subcutaneous adipocytes (Vernon et al., 1995).

In our study, cows fed the HE diet had a larger mesenteric adipose mass and a greater increase in mesenteric mass as final BCS increased compared with LE cows (Figure 1). The percentages of total abdominal adipose mass as omental, mesenteric, and perirenal adipose did not differ significantly between diets (data not presented). However, feeding the HE diet resulted in a different relationship between omental and mesenteric adipose as fat deposition increased (Figure 2); moreover, final weights of carcass and mesenteric fat were not strongly correlated $(\mathrm{r}=0.39)$. Across all cows, final BCS was correlated $(\mathrm{r}=0.66)$ with total abdominal adipose mass and total visceral adipose mass $(\mathrm{r}=$ $0.62)$, but was correlated more strongly with perirenal $(\mathrm{r}=0.72)$ than with omental $(\mathrm{r}=0.57)$ or mesenteric $(\mathrm{r}=0.59)$ adipose masses. Despite these correlations, however, mean BCS did not differ between groups and therefore may lack the sensitivity to differentiate dietary energy effects on visceral adipose tissue accumulation. If similar changes occur in pregnant dry cows, excess energy consumption and the resulting visceral fat accumulation could increase risks for hepatic lipidosis and peripartal metabolic disorders (Drackley et al., 2005; Sordillo et al., 2009). Our previous results demonstrating that low-energy diets effectively limit postpartal increases in NEFA, BHBA, and liver fat (Dann et al., 2006; Richards et al., 2009; Janovick et al., 2011; Graugnard et al., 2012; Ji et al., 2012) are consistent with preventing such enhanced visceral fat accumulation.

Few data are available on diet-induced changes in visceral adipose tissue mass in dairy cows, particularly in nonlactating cows. Reynolds et al. (2004) found that supplemental barley during the dry period increased BCS; mesenteric fat weight, but not omental fat weight, was increased in supplemented cows. Martins et al. (2011) found that bulls had more pronounced changes in mesenteric and omental fat than in subcutaneous or perirenal fat when fed a high-concentrate diet $(70 \%$ concentrate, $30 \%$ corn silage) compared with a high-silage diet ( $70 \%$ corn silage, $30 \%$ concentrate), although interpretation is confounded by differences in ME intake between diets. McLeod et al. (2007) found that abomasal infusion of glucose increased omental and total alimentary adiposity in steers more than infusion of partial starch hydrolysate. In addition, a greater rumen starch availability increased rumen mass, whereas a greater intestinal carbohydrate delivery did not affect gastrointestinal organ mass (McLeod et al., 2007). Conceivably, the increased omental and mesenteric adipose mass for cows fed HE may have been partially attributable to increased duodenal nutrient supply and small intestinal nutrient assimilation. The much greater energy intake by HE cows than by LE cows may have increased arterial acetate incorporation into omental fat and increased glucose delivery to mesenteric fat as shown in steers (Baldwin et al., 2007).

\section{CONCLUSIONS}

Offering a high-energy diet compared with a lowenergy diet for 8 wk to nonlactating cows resulted in greater final BW and increased omental, mesenteric, and perirenal adipose tissue masses without significant differences in BCS or carcass weight. Results indicate that BCS may not be sensitive enough over the short term of a dry period to detect changes of internal fat stores that could affect metabolism and peripartal health.

\section{ACKNOWLEDGMENTS}

The authors gratefully thank the staff at the Dairy Cattle Research Unit of the University of Illinois (Urbana) for care of cows during the experiment. 


\section{REFERENCES}

Anonymous. 2005. Analysis of covariance (ANCOVA) or dummy variable regression (DVR). Handout 4, SAS Workshop-GLM, University of Idaho, College of Agriculture. Accessed Jan. 3, 2011. http://www.uiweb.uidaho.edu/ag/statprog/sas/workshops/glm/ acov.htm

AOAC International. 2000. Official Methods of Analysis. 17th ed. AOAC International, Gaithersburg, MD.

Baldwin, R. L. VI, K. R. McLeod, J. P. McNamara, T. H. Elsasser, and R. G. Baumann. 2007. Influence of abomasal carbohydrates on subcutaneous, omental, and mesenteric adipose lipogenic and lipolytic rates in growing beef steers. J. Anim. Sci. 85:2271-2282.

Batra, A., and B. Siegmund. 2012. The role of visceral fat. Dig. Dis. 30:70-74.

Blaxter, K. L., F. W. Wainman, and R. S. Wilson. 1961. The regulation of food intake in sheep. Anim. Prod. 3:51-62.

Butler-Hogg, B. W., J. D. Wood, and J. A. Bines. 1985. Fat partitioning in British Friesian cows: The influence of physiological state on dissected body composition. J. Agric. Sci. (Camb.) 104:519-528.

Caesar, R., M. Manieri, T. Kelder, M. Boekschoten, C. Evelo, M. Müller, T. Koostra, S. Cinti, R. Kleemann, and C. A. Drevon. 2010. A combined transcriptomics and lipidomics analysis of subcutaneous, epididymal and mesenteric adipose tissue reveals marked functional differences. PLoS ONE 5:e11525.

Carlson, D. B., J. W. McFadden, A. D'Angelo, J. C. Woodworth, and J. K. Drackley. 2007. Dietary L-carnitine affects periparturient nutrient metabolism and lactation in multiparous cows. J. Dairy Sci. 90:3422-3441.

Catalano, K. J., D. Stefanovski, and R. N. Bergman. 2010. Critical role of the mesenteric depot versus other intra-abdominal adipose depots in the development of insulin resistance in young rats. Diabetes 59:1416-1423.

Dann, H. M., N. B. Litherland, J. P. Underwood, M. Bionaz, A. D'Angelo, J. W. McFadden, and J. K. Drackley. 2006. Diets during far-off and close-up dry periods affect periparturient metabolism and lactation in multiparous cows. J. Dairy Sci. 89:3563-3577.

Douglas, G. N., T. R. Overton, H. G. Bateman II, H. M. Dann, and J. K. Drackley. 2006. Prepartal plane of nutrition, regardless of dietary energy source, affects periparturient metabolism and dry matter intake in Holstein cows. J. Dairy Sci. 89:2141-2157.

Drackley, J. K., H. M. Dann, G. N. Douglas, N. A. Janovick Guretzky, N. B. Litherland, J. P. Underwood, and J. J. Loor. 2005. Physiological and pathological adaptations in dairy cows that may increase susceptibility to periparturient diseases and disorders. Ital. J. Anim. Sci. 4:323-344.

Dusserre, E., P. Moulin, and H. Vidal. 2000. Differences in mRNA expression of the proteins secreted by the adipocytes in human subcutaneous and visceral adipose tissues. Biochim. Biophys. Acta 1500:88-96.

Ferrell, C. L., W. N. Garrett, N. Hinman, and G. Grichting. 1976. Energy utilization by pregnant and non-pregnant heifers. J. Anim. Sci. $42: 937-950$.

Gabriely, I., X. H. Ma, X. M. Yang, G. Atzmon, M. W. Rajala, A. H. Berg, P. Scherer, L. Rossetti, and N. Barzilai. 2002. Removal of visceral fat prevents insulin resistance and glucose intolerance of aging: An adipokine-mediated process? Diabetes 51:2951-2958.

Gibb, M. J., W. E. Ivings, M. S. Dhanoa, and J. D. Sutton. 1992. Changes in body components of autumn-calving Holstein-Friesian cows over the first 29 weeks of lactation. Anim. Prod. 55:339-360.

Graugnard, D. E., M. Bionaz, E. Trevisi, K. M. Moyes, J. L. SalakJohnson, R. L. Wallace, J. K. Drackley, G. Bertoni, and J. J. Loor. 2012. Blood immunometabolic indices and polymorphonuclear leukocyte function in peripartum dairy cows are altered by level of dietary energy prepartum. J. Dairy Sci. 95:1749-1758.

Hu, W., M. R. Murphy, P. D. Constable, and E. Block. 2007. Dietary cation-anion difference and dietary protein effects on performance and acid-base status of dairy cows in early lactation. J. Dairy Sci. 90:3355-3366.

Ibrahim, M. M. 2010. Subcutaneous and visceral adipose tissue: Structural and functional differences. Obes. Rev. 11:11-18.
Janovick, N. A., Y. R. Boisclair, and J. K. Drackley. 2011. Prepartum dietary energy intake affects metabolism and health during the periparturient period in primiparous and multiparous Holstein cows. J. Dairy Sci. 94:1385-1400.

Janovick, N. A., and J. K. Drackley. 2010. Prepartum dietary management of energy intake affects postpartum intake and lactation performance by primiparous and multiparous Holstein cows. J. Dairy Sci. 93:3086-3102.

Ji, P., J. S. Osorio, J. K. Drackley, and J. J. Loor. 2012. Overfeeding a moderate energy diet prepartum does not impair bovine adipose tissue insulin signal transduction and induces marked changes in peripartal gene network expression. J. Dairy Sci. 95:4333-4351.

Johnson, M. M., and J. P. Peters. 1993. Technical note: An improved method to quantify nonesterified fatty acids in bovine plasma. J. Anim. Sci. 71:753-756.

Jung, H. G., and M. S. Allen. 1995. Characteristics of plant cell walls affecting intake and digestibility of forages by ruminants. J. Anim. Sci. 73:2774-2790.

Lafontan, M., and J. Girard. 2008. Impact of visceral adipose tissue on liver metabolism. Part I: Heterogeneity of adipose tissue and functional properties of visceral adipose tissue. Diabetes Metab. $34: 317-327$.

Loor, J. J., H. M. Dann, N. A. Janovick Guretzky, R. E. Everts, R. Oliveira, C. A. Green, N. B. Litherland, S. L. Rodriguez-Zas, H. A. Lewin, and J. K. Drackley. 2006. Plane of nutrition prepartum alters hepatic gene expression and function in dairy cows as assessed by longitudinal transcript and metabolic profiling. Physiol. Genomics 27:29-41.

Loor, J. J., N. A. Janovick, R. E. Everts, S. L. Rodriguez-Zas, H. A. Lewin, and J. K. Drackley. 2004. Adipose, mammary, and hepatic gene expression profiling in lactating dairy cows using a bovine cDNA microarray. J. Dairy Sci. 87(Suppl. 1):196-197. (Abstr.)

Martins, A. P., P. A. Lopes, A. S. H. Costa, S. V. Martins, N. C. Santos, J. A. M. Prates, T. F. Moura, and G. Soveral. 2011. Differential mesenteric fat deposition in bovines fed on silage or concentrate is independent of glycerol membrane permeability. Animal 5:1949-1956

McLeod, K. R., R. L. Baldwin VI, M. B. Solomon, and R. G. Baumann. 2007. Influence of ruminal and postruminal carbohydrate infusion on visceral organ mass and adipose tissue accretion in growing beef steers. J. Anim. Sci. 85:2256-2270.

NRC. 2001. Nutrient Requirements of Dairy Cattle. 7 th rev. ed. Natl. Acad. Press, Washington, DC.

Nestel, P. J., A. Poyser, R. L. Hood, S. C. Mills, M. R. Willis, L. J. Cook, and T. W. Scott. 1978. The effect of dietary fat supplements on cholesterol metabolism in ruminants. J. Lipid Res. 19:899-909.

Pike, B. V., and C. J. Roberts. 1984. Size and lipolytic capacity of bovine adipocytes from subcutaneous and internal adipose tissue. Vet. Res. Commun. 8:61-64.

Reynolds, C. K. 2002. Economics of visceral energy metabolism in ruminants: Toll keeping or internal revenue service? J. Anim. Sci. 80(Suppl. 2):E74-E84.

Reynolds, C. K., B. Dürst, B. Lupoli, D. J. Humphries, and D. E. Beever. 2004. Visceral tissue mass and rumen volume in dairy cows during the transition from late gestation to early lactation. J. Dairy Sci. 87:961-971.

Richards, B.F., N.A. Janovick, K.M. Moyes, D.E. Beever, and J.K. Drackley. 2009. Comparison of a controlled-energy high-fiber diet fed throughout the dry period to a two-stage far-off and close-up dietary strategy. J. Dairy Sci. 92(E. Suppl. 1):140. (Abstr.)

Scheaffer, A. N., J. S. Caton, M. L. Bauer, and L. P. Reynolds. 2001. Influence of pregnancy on body weight, ruminal characteristics, and visceral organ mass in beef heifers. J. Anim. Sci. 79:24812490.

Simmons, C. R., W. G. Bergen, M. J. VandeHaar, D. J. Sprecher, C. J. Sniffen, E. P. Stanisiewski, and H. A. Tucker. 1994. Protein and fat metabolism in cows given Somavubove before parturition. J. Dairy Sci. $77: 1835-1847$.

Smith, N. E., and R. L. Baldwin. 1974. Effects of breed, pregnancy, and lactation on weight of organs and tissues in dairy cattle. J. Dairy Sci. 57:1055-1060. 
Smith, R. W., and A. Walsh. 1988. Effects of pregnancy and lactation on the metabolism of bovine adipose tissue. Res. Vet. Sci. 44:349-353.

Sordillo, L. M., G. A. Contreras, and S. L. Aitken. 2009. Metabolic factors affecting the inflammatory response of periparturient dairy cows. Anim. Health Res. Rev. 10:53-63.

Studer, V. A., R. R. Grummer, and S. J. Bertics. 1993. Effect of prepartum propylene glycol administration on periparturient fatty liver in dairy cows. J. Dairy Sci. 76:2931-2939.

Tennant, B. C., and S. A. Center. 2008. Hepatic function. Pages 379 412 in Clinical Biochemistry of Domestic Animals. 6th ed. J. J. Kaneko, J. W. Harvey, and M. L. Bruss, ed. Academic Press, San Diego, CA.

Ulleberg, T., J. Robben, K. M. Nordahl, T. Ulleberg, and R. Heiene. 2011. Plasma creatinine in dogs: Intra- and inter-laboratory variation in 10 European veterinary laboratories. Acta Vet. Scand. $53: 25$.

Van Harmelen, V., F. Lönnqvist, and A. Thorne. 1997. Noradrenalineinduced lipolysis in isolated mesenteric, omental and subcutaneous adipocytes from obese subjects. Int. J. Obes. Relat. Metab. Disord. 21:972-979.

Van Soest, P. J., J. B. Robertson, and B. A. Lewis. 1991. Methods for dietary fiber, neutral detergent fiber, and nonstarch polysaccharides in relation to animal nutrition. J. Dairy Sci. 74:3583-3597.
Vernon, R. G., R. Doris, E. Finley, M. D. Houslay, E. Kilgour, and S. Lindsay-Watt. 1995. Effects of lactation on the signal transduction systems regulating lipolysis in sheep subcutaneous and omental adipose tissue. Biochem. J. 308:291-296.

Vickers, L. A., D. M. Weary, D. M. Viera, and M. A. von Keyserlingk. 2013. Feeding a higher forage diet prepartum decreases incidences of subclinical ketosis in transition dairy cows. J. Anim. Sci. 91:886-894.

Waltner, S. S., J. P. McNamara, J. K. Hillers, and D. L. Brown. 1994 Validation of indirect measures of body fat in lactating cows. J. Dairy Sci. 77:2570-2579.

Wildman, E. E., G. M. Jones, P. E. Wagner, R. L. Boman, H. F. Troutt, and T. N. Lesch. 1982. A dairy cow body condition scoring system and its relationship to selected production characteristics. J. Dairy Sci. 65:495-501.

Wright, I. A., and A. J. F. Russel. 1984. Partition of fat, body composition and body condition score in mature cows. Anim. Prod. 38:23-32.

Yang, Y. K., M. Chen, R. H. Clements, G. A. Abrams, C. J. Aprahamian, and C. M. Harmon. 2008. Human mesenteric adipose tissue plays unique role versus subcutaneous and omental fat in obesity related diabetes. Cell. Physiol. Biochem. 22:531-538. 